DEPARTMENT OF THE INTERIOR

UNITED STATES GEOLOGICAL SURVEY

GEOLOGIC MAP OF THE WINKELMAN QUADRANGLE, PINAL AND GILA COUNTIES, ARIZONA

By Medora H. Krieger

Publisned by the U.S. Geological Survey, 1974

Washington, D.C. 20244 


\title{
GEOLOGIC MAP OF THE WINKELMAN QUADRANGLE, PINAL AND GILA COUNTIES, ARIZONA
}

\author{
By Medora H. Krieger
}

\section{REGIONAL GEOLOGIC SETTING}

The broad regional geologic and structural setting of the Winkelman 15-minute quadrangle, of which the Winkelman $71 / 2$-minute quadrangle is the northeast part, is discussed by Krieger (1974e). Rocks within the general area range in age from Precambrian to Holocene. Except for Pennsylvanian strata, Paleozoic sedimentary rocks are not now exposed in the $71 / 2$-minute quadrangle. Steeply dipping to overturned Precambrian sedimentary rocks are repeated by a tilted thrust.

\section{STRATIGRAPHY}

The oldest Precambrian rocks in the area of the larger scale index map are the Pinal Schist and intrusive rocks, largely the Ruin Granite (Oracle Granite of N.P. Peterson, 1938). Batholithic masses of Ruin Granite (1,430 m.y.) were intruded after a period of intense deformation that produced near-vertical east-trending foliation and bedding in the schist. The schist and granite are overlain with profound angular unconformity by Precambrian sedimentary rocks--the Apache Group and the disconformably overlying Troy Quartzite. Diabase, about 1,200 m.y. old (Silver, 1960; Damon and others, 1962), forms sills in the Apache Group and Troy Quartzite, sill-like masses in the schist and granite generally parallel to, and not more than 500 feet below, the pre-Apache surface (Shride, 1967, p. 56), and some dikes. The sills inflated, but did not perceptibly tilt, the Precambrian sedimentary rocks.

After a long period of erosion, Paleozoic formations were deposited paraconformably on the Precambrian sedimentary rocks and diabase.

Volcanic rocks of Late Cretaceous age disconformably overlie older rocks in the area of the larger scale index map. One of these formations, the Williamson Canyon Volcanics of andesitic composition, has been considered either Late Cretaceous (Willden, 1964) or Late Cretaceous and(or) early Tertiary (Simons, 1964; Creasey, $1965,1967)$. It is now considered Late Cretaceous because the Williamson Canyon Volcanics in the northeast part of the Crozier Peak quadrangle is intruded by diorite that in the Winkelman $71 / 2$-minute quadrangle is dated as Late Cretaceous.

Late Cretaceous diorite and granodiorite and Late Cretaceous and(or) early Tertiary (Laramide) porphyry masses of several lithologic types intrude the older rocks.

Cenozoic stratigraphy in eastern Pinal County has recently been revised by Krieger and others (1973). In the area of the larger scale index map, Tertiary sedimentary deposits, formerly called Gila Conglomerate or Group, are now divided into three formations--in ascending order, the San Manuel, Big Dome, and Quiburis. In addition, Pleistocene and Holocene alluvial deposits, also formerly included in the Gila Conglomerate or Group, overlie these formations.

The San Manuel Formation consists of alluvial and playa deposits and interbedded andesite and megabreccias. It is Miocene (probably early Miocene) in age. Discordant dates on biotite and sanidine from a rhyodacite tuff bed in its upper part in the Crozier Peak quadrangle are 18 and 24 m.y., respectively (Joan Engels, written communication, 1968). The San Manuel Formation is clearly overlain unconformably by the alluvial Big Dome Formation in the Kearny and Crozier Peak quadrangles. In the Kearny quadrangle, an interbedded, nonwelded ash-flow tuff yields late Miocene $\mathrm{K}$-Ar ages of $14 \mathrm{~m} . \mathrm{y}$. on biotite and $17 \mathrm{~m} . \mathrm{y}$. on hornblende (Cornwall and others, 1971; Banks and others, 1972). The youngest of these formations, the Quiburis Formation, which consists of an alluvial and a lakebed facies, was deposited in the basin now occupied by the San Pedro River. It contains Hemphillian vertebrate fossils, indicating a middle Pliocene age.

STRUCTURE

The major structural features in the Winkelman 15-minute quadrangle southwest of the San Pedro and Gila Rivers, are high-angle faults, north-northwesttrending en echelon ridges of steeply dipping to overturned Precambrian and Paleozoic sedimentary rocks and diabase, and low-angle gravity slides. As the tops of the beds in the en echelon ridges always face east, the structures are interpreted as partly eroded roots of a single monoclinal fold later separated by faults, or possibly as a series of monoclinal folds. Locally the section within an individual ridge is repeated along what appears on a map as a high-angle fault, but which is inferred to be a tilted thrust. Some of the faulting, monoclinal folding, tilting of the thrusts, uplift, and the erosion of large areas now stripped of Precambrian and Paleozoic sedimentary rocks, occurred before deposition of the San Manuel Formation, for the oldest unit in that formation in the Putnam Wash quadrangle is composed largely of Precambrian granite clasts. Intense deformation also occurred after deposition of the San Manuel Formation, for, adjacent to the monoclinal ridges, the formation dips steeply though somewhat less than the older rocks. The formation has also been cut by low-angle gravity slides and high-angle faults.

Faults that predate the San Manuel Formation are the thrusts, now tilted to vertical or overturned, and two sets of high-angle faults that trend east-northeast and north. Some east-northeast-trending faults resemble tear faults related to the thrusting, especially in the Crozier Peak quadrangle.

The Romero Wash fault, a tilted thrust, apparently consists of a single strand, in contrast to the Ripsey 
Wash fault (Crozier Peak quadrangle), which is a multiple strand fault. East of the Romero Wash fault either Ruin Granite or Pinal Schist underlies the Apache Group in some areas; elsewhere the Apache Group section is repeated without intervening schist or granite. The Romero Wash fault is now occupied by a Late Cretaceous dike throughout most of its exposed southern part and is presumed to lie within diabase in its northern part where faults are difficult to recognize.

Faults that postdate the San Manuel Formation are west-dipping low-angle gravity slides, high-angle northnorthwest-trending faults, at least some of which cut the gravity slides, and a few east-northeast-trending faults. Some high-angle faults, or some of the movement on them, also postdate the Big Dome Formation; a few postdate the Quiburis Formation.

A low-angle, west-dipping gravity slide, the Camp Grant fault, separates Ruin Granite on the east from steeply east-dipping San Manuel Formation in the southeastern part of the Putnam Wash quadrangle. The probable offset portion of this fault extends into the

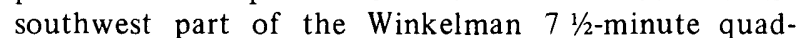
rangle, where it also involves Precambrian rocks. The Smith Wash fault in the northwest part of the Winkelman $71 / 2$-minute quadrangle may be of similar age and origin. Some movement has occurred along the contacts between the San Manuel Formation and bedrock, but the amount of displacement in most places may be small.

\section{MINERALIZATION}

The Winkelman 15-minute quadrangle (of which the Winkelman $71 / 2$-minute quadrangle is a part) is adjacent to three major copper deposits: the San Manuel to the southeast, the Christmas to the northeast, and the Ray to the northwest. Although no economic deposits have yet been found within the 15-minute quadrangle, numerous prospect pits, shafts, and adits have explored the principal mineralized areas, which are in granitic rocks in the southeast corner and in the north-central and northwestern parts of the 15-minute quadrangle. Some of the mineralization may be Precambrian in age, but most of it probably is related to Late Cretaceous and(or) early Tertiary intrusive bodies.

In the Winkelman $7 \frac{1}{2}$-minute quadrangle the most extensively mineralized and explored area is between the north branch of Romero and the north branch of Smith Washes, locally referred to as the Copper Hill area (Evensen, 1961). Quartz-sericite alteration is common, and tiny pyrite crystals are widely disseminated accompanied by limonitic alteration and copper staining. In the breccia pipe(?) on the north side of the north branch of Smith Wash (SW1/4 sec. 25, T. 5 S., R. 14 E.), the granodiorite has been altered to a fine-grained mixture of quartz, sericite, and natrojarosite (hydrous $\mathrm{NaFe}$ sulfate), with goethite veining the natrojarosite. A few pyrite cubes, less than $1 \mathrm{~cm}$ in size, were noted on the dump. Rounded cobble- and boulder-sized masses of altered rock suggest breccia pipe formation. No copper mineralization was noted in the breccia pipe, but copper mineralization is widespread south of the pipe. Several prospects occur south of Romero Wash. At the Sample mine, east of Horse Hills, mineralization consists of quartz veins and limonitic staining from pyrite; chalcocite and malachite were observed on the dump. A prospect on an east-trending shear zone that cuts diabase and Pinal Schist on the north side of Swingle
Wash, SW $1 \frac{1}{4}$ sec. 17, T. 6 S., R. 15 E., contains small galena crystals, mottramite $\left(\mathrm{Cu}(\mathrm{Zn}) \mathrm{PbVO}_{4}\right)$, and wellcrystallized needles of goethite.

\section{DESCRIPTION OF MAP UNITS}

\section{SURFICIAL DEPOSITS}

Alluvium (0-15 ft exposed).-Valley bottoms, floodplain deposits, composed of clay, silt, sand, and some gravel; largely unconsolidated. Large areas on gently sloping surfaces are essentially stripped and dissected pediment surfaces cut on gravel and sand of Pleistocene age or on the lake-bed facies of the Quiburis Formation. In these areas alluvium is being carried along each of the innumerable small washes; patches of older deposits and remnants of pediment soil and gravel are exposed locally.

Talus (0 - about $20 \mathrm{ft}$ exposed).-Veneer of rock debris derived from adjacent bedrock. Many talus deposits, not identified on the map, partly cover diabase, upper member of the Dripping Spring Quartzite, and the Pioneer Formation.

Soil and gravel veneer on pediments and younger terraces $10-25 \mathrm{ft})$.-Subangular pebbles and cobbles in a generally reddish-brown, fine- to coarse-grained matrix. Pediments are developed mostly on gravels and sands of Pleistocene age and on lake-bed facies of the Pliocene Quiburis Formation; many are partly dissected; the intervening slopes and valley bottoms are covered by colluvium and alluvium. The dark red-brown soils were developed during one of the pre-Wisconsin interglaciations.

Undifferentiated gravel.-Small patches of terrace or pediment gravels, talus, and alluvium; includes isolated exposures of older gravels.

\section{SAND AND GRAVEL (0-POSSIBLY 200 FT)}

Poorly exposed, light-colored essentially unconsolidated alluvial gravel and sand, largely composed of granitic material, probably thinly covers much of the eastern part of the quadrangle but is concealed in many places by younger alluvium. Includes unmapped exposures of Quiburis and San Manuel Formations. Probably deposited after inception of through-going drainage along the San Pedro and Gila Rivers. The unit is considered early and (or) middle Pleistocene because of its unconsolidated character and stratigraphic position above the middle Pliocene Quiburis Formation and below the red pediment soils.

QUIBURIS FORMATION (0-AT LEAST 600 FT EXPOSED)

Named by Heindl (1963): see also Krieger and others (1973); called Gila Conglomerate by Krieger (1968c, d) and Creasey $(1965,1967)$. An alluvial and a fine-grained lakebed facies deposited in a long, narrow closed basin. In most places the two facies intertongue through a distance generally of less than a quarter of a mile. The alluvial facies in exposed parts of the basin does not encroach over the lakebed facies, indicating absence of partial drying up of the lake. Very locally, lakebeds extend westward across the alluvial deposits, probably indicating embayments along tributary valleys. Approximate position of the buried contact between the two facies beneath younger gravels is shown on the map. Position of the contact at the north edge of the quadrangle was determined by mapping immediately to the north in the Hayden quadrangle, where both facies are exposed. Considered middle Pliocene in age because of the presence of vertebrate fossils in presumably equivalent lakebeds south of Mammoth. J.F. Lance stated 
(oral commun., 1963) only that the fossils are preBlancan, but he now considers them definitely Hemphillian in age, according to K.E. Lohman (written commun., from Lance in McAllister, 1970, p. 6).

Alluvial facies.-Grayish-red, pale- to light-brown, and light-brownish-gray sandy pebble-conglomerate and some interbedded sandy and silty beds; subangular to subrounded clasts, generally less than 4 inches in maximum size, are of Pinal Schist, Apache Group rocks, some diabase, and a little Ruin Granite; granite is locally more abundant in western exposures where the facies laps up onto granitic fanglomerate of the Big Dome Formation. Clasts derived from Paleozoic limestone, Late Cretaceous granodiorite, and Williamson Canyon Volcanics are abundant in northeast corner of map area. Contacts between the Quiburis and younger and older granitic gravels are very arbitrarily placed.

Lake-bed facies.-Thin- and evenly bedded, grayishorange-pink to yellowish-gray clay, silt, marl, and very fine-grained sand; forms vertical cliffs along some washes; elsewhere largely concealed by younger gravels, many not identified on the map. Contains thin beds of gypsum, especially north of lower Swingle Wash; commercial deposits of gypsum are quarried east of the San Pedro in the Lookout Mountain and Saddle Mountain quadrangles. In these two quadrangles thin beds of rhyolite tuff have been noted. Deposits of diatoms in rhyolite tuff (first described by Blake, 1903) occur near the vertebrate fossil locality (sec. 29 , T. 9 S., R. 18 E., Mammoth 15-minute quadrangle). According to K.E. Lohman (written communication to McAllister, 1967), who studied the San Pedro Valley assemblage from specimens supplied by Lance, the diatoms probably were deposited in a shallow lake or in the shallow margin of a deeper lake. A number of species characteristic of hot springs, present in the assemblage, strongly suggest subaqueous hot spring activity in the lake itself or in streams feeding into the lake. The presence of arborescent manganese concretions (6 in. or more high) in the lake-bed facies (NE $1 / 4$ sec. 29, T. 7 S., R. 17 E., Holy Joe Peak quadrangle) also suggests hot springs.

BIG DOME FORMATION

Thickness unknown, probably not more than a few hundred feet in this area. - Named by Krieger and others (1973) for exposures at Big Dome, Sonora quadrangle, where it was mapped but not named by Cornwall and others (1971). Outcrops north of Smith Wash in the Winkleman quadrangle are clearly part of the Big Dome Formation in the Kearny quadrangle. Outcrops south of Smith Wash probably are part of the Big Dome Formation. Mostly yellowish-gray to light-gray; derived largely from Ruin Granite and related rocks. Some lenses contain scattered to abundant clasts of Precambrian sedimentary rocks and diabase, Paleozoic, and Cretaceous and(or) early Tertiary rocks, in a granitic matrix; beds of rhyolite tuff locally. Clasts generally pebble- to cobblesized, large boulders locally; mostly subangular to subrounded. Generally poorly indurated and poorly exposed, except for northernmost outcrops.

\section{SAN MANUEL FORMATION (MORE THAN 2,000 FT)}

Named by Heindl (1963). The formation, which has been separated into three units in this quadrangle, lies east of the ridge of Apache Group rocks and extends for an unknown distance to the east beneath younger deposits. Small remnants are present north of James Wash in the southwest part of the map.
Younger granitic alluvial deposits (thickness unknown). - Yellowish- to yellowish-gray, light-olive-gray and very light gray alluvial or fanglomeratic deposits compused largely of light-colored granitic clasts; some clasts of Apache Group rocks, diabase, Late Cretaceous and(or) early Tertiary intrusive rocks, and Tertiary(?) andesite. Clasts of Precambrian sedimentary rocks and diabase more abundant close to contact with nongranitic deposits; locally brown or red cast due mainly to abundant clasts of brown or red granitic rocks. A few thin beds of carbonate (fresh-water limestone ?) and of rhyolite tuff. Material ranges from sand and silt to rare boulders of 6 - $\mathrm{ft}$ maximum size; mostly subangular to subrounded. Granitic clasts generally larger than nongranitic clasts where both are present. Matrix largely granitic. Unit is generally not well sorted, indurated, or exposed, but may be well sorted and indurated locally, especially north of Romero Wash.

Nongranitic alluvial deposits 10 - at least $1,500 \mathrm{ft}$ exposed).-Olive-gray to light-olive-gray and locally very light gray conglomerate and sandstone composed of clasts of many older rocks; contains little Ruin Granite and related rocks. Darker colored beds generally have abundant clasts of Tertiary andesite and(or) Cretaceous mafic volcanic rocks; Pinal Schist is abundant in southern exposures; some very light colored beds are composed largely of Paleozoic limestone and a little Troy(?) quartzite. A few thin beds of white rhyolite tuff were observed in northern outcrops. Material ranges from silt and sand to local boulders $3 \mathrm{ft}$ in diameter, rarely, $6 \mathrm{ft}$. Much of it is pebbles to cobbles in a sand-sized matrix, interbedded with thin beds of sandstone. Some sandy beds have sparse angular fragments, 2 to 3 in. long, rarely 6 to 8 in. long. Sorting ranges from good to poor; eastern beds are generally well sorted. Bedding is fairly well developed; beds generally are less than $1 \mathrm{ft}$ thick. The northern outcrops are part of the non-granitic alluvial deposits in the Hayden quadrangle. These deposits in the Kearny quadrangle grade into playa deposits in which mud cracks and curled mud chips are common. None were noted in the Winkelman quadrangle, but some of the bedding features--lateral extent of thin beds, and absence of channeling--are similar to those in the playa deposits to the northwest. Most of the material, however, probably is alluvial. In most places the unit is well indurated and well exposed, but north and south of Sample Wash it is poorly exposed.

Older granitic alluvial deposits.-Poorly exposed and poorly consolidated, coarse- to fine-grained pale-red to yellowish-gray alluvial deposits composed largely of granitic rocks; along James Wash, southwest part of quadrangle.

\section{ANDESITE OF DEPRESSION CANYON(?)}

Dark- to light-gray, pale-brown to grayish-red, nonvesicular to vesicular and amygdaloidal andesitic flows and agglomerate containing 1-2 mm phenocrysts of olivine and (or) pyroxene in an aphanitic groundmass composed of plagioclase, augite, olivine, and opaque minerals. Unconformably overlain by the Quiburis Formation; questionably correlated with andesite of Depression Canyon, one of the older andesite units in the early Miocene Galiuro Volcanics (Krieger, $1968 \mathrm{a}$-d). It may be essentially the same age as andesite interbedded in the San Manuel Formation in the Crozier Peak quadrangle. 
DIKES, SILLS, AND IRREGULAR INTRUSIVE BODIES

Dikes, sills, plugs, and irregular igneous masses intrude Ruin Granite, Apache Group, and diabase; many small ones are not represented. At least some of the northtrending ones are older than some east-trending ones. They fill older north-trending structures that are displaced by east-trending faults, some of which are intruded by dikes. Dikes not classified during the mapping are shown as unclassified (TKu). Many of them are of rhyodacite porphyry, but other types are included.

\section{DIKES}

Quartz latite porphyry.-Rhyolitic to quartz latitic in composition. White to very light gray aphanitic rock with phenocrysts (1-2 $\mathrm{mm})$ of quartz and feldspar. Tentatively correlated with the younger quartz latite porphyry dikes of the Crozier Peak quadrangle; probably older than Miocene rhyolite dikes in the Putnam Wash quadrangle (Krieger, 1974b and d).

Hornblende porphyry. - Light- to medium-light, slightly greenish-gray rock with abundant fresh or altered hornblende needles and laths 5-10 mm long, a few $5-\mathrm{mm}$ plagioclase phenocrysts in a fine-grained, generally altered groundmass composed of plagioclase laths, hornblende needles, magnetite, epidote, apatite, and interstitial K-feldspar. Most of these dikes probably are melanocratic rhyodacite in composition, although the two north of Sample Wash, sec. 14, T. $6 \mathrm{~S}$., R. 14 E., may be andesitic in composition.

Rhyodacite porphyry.-Light-gray to light-brownishgray; abundant plagioclase phenocrysts and less abundant hornblende and biotite phenocrysts in a creamy aphanitic groundmass. Feldspar phenocrysts, mostly 1-3 mm long, make up 30 percent of rock; mafic phenocrysts, 1-2 mm long, present in about equal amounts. May be closely related to granodiorite.

IRREGULAR INTRUSIVE MASSES, SILLS, AND SOME DIKES

Granodiorite.-Two irregular masses intrude Ruin Granite and Late Cretaceous diorite (Kdi) north and south of Smith Wash. Very light to medium gray with phenocrysts of nearly white plagioclase and black to greenish-black biotite and hornblende; very light gray, fine-grained groundmass. Zoned plagioclase generally more abundant and larger $(3-5 \mathrm{~mm})$ than mafic phenocrysts. Biotite books, mostly $2 \mathrm{~mm}$ in diameter rarely $5 \mathrm{~mm}$, and hornblende laths, mostly smaller than biotite, but locally $1 \mathrm{~cm}$ long. Groundmass minerals, generally less than $1 \mathrm{~mm}$ in grain size, consist of plagioclase, K-feldspar, quartz, mafic minerals, magnetite, and ilmenite. The granodiorite ranges from medium grained with a seriate texture to a porphyry with an aphanitic groundmass, but most of it is fine grained and porphyritic. Much of the rock weathers to rounded boulders. Where altered, the groundmass takes on a pinkish cast and mafic minerals become greenish gray. Hornblende is generally more altered than biotite. Pyrite is common in some of the altered rocks. Biotite from the eastern part of this mass gave an age of $66.0 \pm$ 2.0 m.y. by the K-Ar method and biotite from a chilled offshoot or a younger rhyodacite dike gave an age of $65.7 \pm 2.0$ m.y., according to R.F. Marvin (U.S. Geol. Survey, written commun., 1966). The chemical and normative compositions of these two specimens are given in table 1. Damon and others (1964, Cooper Hill quartz monzonite, p. 48; see also Evensen, 1961) obtained a date of $68 \mathrm{~m} . \mathrm{y}$. from biotite in this mass. The granodiorite is cut by aplite dikes.

Hornblende diorite. - An irregular mass, part of a larger mass to the east and north, intrudes Naco Limestone and Williamson Canyon Volcanics in the northeast part of the quadrangle. Light- to medium-light-gray; mostly small phenocrysts of hornblende and plagioclase in a fine-grained groundmass. Associated with the hornblende diorite are numerous darker colored aphanitic porphyries, probably related to the hornblende diorite; some of these are difficult to distinguish from the Williamson Canyon Volcanics. Much of the hornblende diorite is extensively altered. In the Saddle Mountain quadrangle the hornblende diorite was called diorite, and in the Christmas quadrangle it was called microdiorite.

Diorite.-Medium-dark-gray, fine- to medium-grained (mostly less than $2 \mathrm{~mm}$ ) rock composed of plagioclase, hornblende, biotite, magnetite, a little pyroxene and quartz, and a very small amount of K-feldspar; most of the $\mathrm{K}_{2} \mathrm{O}$ (table 2) is probably in the biotite. Plagioclase generally slightly grayish in thin section due to dustlike inclusions; a few larger ones, as much as $8 \mathrm{~mm}$, are zoned. A few hornblende phenocrysts are 2-4 mm long; most of the hornblende is pale green; much of it and the pyroxene are altered to chlorite. Epidote and sericite are other alteration products. The diorite masses trend roughly east-west and have a pronounced eastwest grain that is visible from a distance and on air photos. West of the quadrangle, part of this grain is caused by lenses of Williamson Canyon Volcanics; some of it is due to intrusion of andesite porphyry and quartz latite porphyry dikes, but much of it may be due to differences in grain size, perhaps caused by successive injections of diorite. Hornblende from the diorite gave an isotopic age of $65.6 \pm 2.0 \mathrm{~m} . \mathrm{y}$. by the K-Ar method, according to Joan Engels (written commun., 1968). The chemical and normative compositions are given in table 2 . The diorite is clearly older than the granodiorite and may be about the same age $(71 \mathrm{~m} . y$. , biotite; $82 \mathrm{~m} . \mathrm{y}$. hornblende) as the Tortilla Quartz Diorite in the Sonora quadrangle (see also Banks and others, 1972).

Fine-grained quartz diorite-Medium-dark- to medium-light-gray and olive-gray, fine-grained rock with a few widely scattered 1-2 mm phenocrysts of plagioclase in a groundmass of plagioclase (mostly altered to zoisite and epidote), quartz, epidote, chlorite, magnetite, Kfeldspar, and calcite. The longest dike, from a few feet to about $250 \mathrm{ft}$ wide, was intruded into Romero Wash fault throughout most of its $3-1 / 2$ mile exposed extent from Swingle Wash to the northern branch of Romero Wash. The narrow east-trending dike on the south side of Romero Wash (SE cor. sec. 1, T. 6 S., R. 14 E.) is identical to the north-trending dike. The northeasttrending dike in $\mathrm{NE}^{1 / 4} \mathrm{sec} .11, \mathrm{~T} .6 \mathrm{~S}$., R. $14 \mathrm{E}$., is a dark-gray, very fine-grained rock, questionably related to the north-trending dike.

Older rhyodacite porphyry.-Mostly medium- to light(locally medium- dark-) gray with a greenish, brownish, or olive cast. Plagioclase $(3-7 \mathrm{~mm})$, the most conspicuous phenocryst (except in some badly altered rocks), generally makes up 20-30 percent of the rock. Mostly smaller $(2.3 \mathrm{~mm})$ euhedral phenocrysts of hornblende, biotite, and (smaller) magnetite; little quartz visible in most hand specimens. The groundmass is aphanitic. Plagioclase, hornblende, biotite, and the groundmass mostly altered; alteration products are chlorite, epidote, some sericite, granular magnetite, and calcite. 
TABLE 1.-Chemical and normative composition of granodiorite.

[Analyses under the direction of Leonard Shapiro, methods given in U.S. Geological Survey Bull. 1144-A]

\begin{tabular}{|c|c|c|c|c|c|}
\hline Field No. & W-65 A & $. \mathrm{W}-86$ & & W-65A & W-86 \\
\hline \multicolumn{3}{|c|}{$\begin{array}{c}\text { Chemical composition } \\
\text { (in percent) }\end{array}$} & \multicolumn{3}{|c|}{$\begin{array}{l}\text { CIPW Norms. } \\
\text { (wt percent) }\end{array}$} \\
\hline $\mathrm{SiO}_{2}$ & 65.8 & 64.1 & Q & 24.9 & 23.8 \\
\hline $\mathrm{Al}_{2} \mathrm{O}_{3}$ & 16.2 & 16.3 & $\mathrm{c}$ & .8 & 3.2 \\
\hline $\mathrm{Fe}_{2} \mathrm{O}_{3}$ & 2.9 & 1.4 & or & 14.3 & 12.2 \\
\hline $\mathrm{Fe} 0$ & 1.1 & 2.8 & $a b$ & 33.4 & 35.0 \\
\hline $\mathrm{Mg} 0$ & 1.8 & 2.4 & an & 17.7 & 12.5 \\
\hline $\mathrm{CaO}$ & 3.8 & 2.8 & en & 4.5 & 6.2 \\
\hline $\mathrm{Na}_{2} \mathrm{O}$ & 3.9 & 4.0 & fs & 0 & 3.0 \\
\hline $\mathrm{K}_{2} \mathrm{O}$ & 2.4 & 2.0 & $\mathrm{mt}$ & 1.8 & 2.1 \\
\hline $\mathrm{H}_{2} \mathrm{O}^{-}$ & .28 & .47 & $\mathrm{hm}$ & 1.7 & 0 \\
\hline $\mathrm{H}_{2} \mathrm{O}+$ & .72 & 2.5 & il & 1.3 & 1.4 \\
\hline $\mathrm{TiO}_{2}$ & .68 & .72 & ap & .5 & .7 \\
\hline $\mathrm{P}_{2} \mathrm{O}_{5}$ & .20 & .27 & Total & $\frac{1}{1} 100.9$ & $t_{100.1}$ \\
\hline $\begin{array}{l}\mathrm{Mn} 0 \\
\mathrm{CO}_{2}\end{array}$ & $\begin{array}{r}.07 \\
<.05\end{array}$ & $\begin{array}{r}.04 \\
<.05\end{array}$ & \multirow{2}{*}{$\begin{array}{l}\text { Salic } \\
\text { Femic }\end{array}$} & \multirow{2}{*}{$\begin{array}{r}90.2 \\
9.8\end{array}$} & \multirow{2}{*}{$\begin{array}{l}86.7 \\
13.3\end{array}$} \\
\hline \multirow{2}{*}{ Sum } & \multirow{2}{*}{100} & \multirow{2}{*}{100} & & & \\
\hline & & & \multicolumn{3}{|c|}{$\begin{array}{l}\text { I/In calculating the norms, } \\
\text { both } \mathrm{H}_{2} \mathrm{O} \text { - and } \mathrm{H}_{2} \mathrm{O}+\text { were } \\
\text { omitted }\end{array}$} \\
\hline
\end{tabular}

W-65A - Granodiorite near SE cor. sec. 25, T. 5 S., R. $14 \mathrm{E}$.

W-86 - Chilled offshoot or a younger rhyodacite dike, NW $1 / 4$ sec. 31, T. 5 S., R. 15 E.

TABLE 2.-Chemical and normative compositions of diorite, SE1/4 sec. 25, T. 5 S., R 14.E.

[Analysis under the direction of Leonard Shapiro, methods given in U.S. Geol. Survey Bull. 1144-A]

\begin{tabular}{|c|c|c|c|}
\hline \multicolumn{4}{|c|}{ Field No. W-83 } \\
\hline \multicolumn{2}{|c|}{$\begin{array}{l}\text { Chemical composition } \\
\text { (in percent) }\end{array}$} & \multicolumn{2}{|c|}{$\begin{array}{l}\text { CIPW Norms } \\
\text { (wt percent) }\end{array}$} \\
\hline $\mathrm{SiO}_{2}$ & 53.3 & $\mathrm{Q}$ & 6.0 \\
\hline $\mathrm{Al}_{2} \mathrm{O}_{3}$ & 18.0 & or & 7.9 \\
\hline $\mathrm{Fe}_{2} \mathrm{O}_{3}$ & 3.9 & $a b$ & 26.9 \\
\hline $\mathrm{Fe} 0$ & 5.1 & an & 32.1 \\
\hline $\mathrm{Mg} 0$ & 4.6 & wo & 2.3 \\
\hline $\mathrm{CaO}$ & 7.8 & en & 11.7 \\
\hline $\mathrm{Na}_{2} \mathrm{O}$ & 3.1 & fs & 6.4 \\
\hline $\mathrm{K}_{2} \mathrm{O}$ & 1.3 & $\mathrm{mt}$ & 5.8 \\
\hline $\mathrm{H}_{2} \mathrm{O}^{-}$ & .16 & il & .2 \\
\hline $\mathrm{H}_{2} \mathrm{O}+$ & 1.0 & ap & .7 \\
\hline $\mathrm{TiO}_{2}$ & 1.0 & \multicolumn{2}{|c|}{ Total $1 / 100$} \\
\hline $\mathrm{P}_{2} \mathrm{O}_{5}$ & .30 & Salic & 72.9 \\
\hline $\begin{array}{l}\mathrm{Mn0} \\
\mathrm{CO}_{2}\end{array}$ & $\begin{array}{r}.16 \\
<.05\end{array}$ & Femic & 27.1 \\
\hline Sum & 100 & \multicolumn{2}{|c|}{$\begin{array}{l}{ }^{1} \text { In calculating the norms } \\
\text { both } \mathrm{H}_{2} \mathrm{O}-\text { and } \mathrm{H}_{2} \mathrm{O}+\text { wer } \\
\text { omitted }\end{array}$} \\
\hline
\end{tabular}

\section{WILLIAMSON CANYON VOLCANICS}

Named by Simons (1964, p. 44-47); see also Krieger (1968d); called unnamed volcanic and sedimentary rocks by Willden (1964, p. E26-E27). Massive porphyritic to nonporphyritic andesitic breccia, agglomerate, tuff, flow, flow breccia, and volcanic conglomerate. Shades of red, brown, and gray. Phenocrysts are of plagioclase and hornblende. Phenocrysts and groundmass extensively altered to various mixtures of epidote, calcite, chlorite, sericite, magnetite, and hematite.

\section{NACO LIMESTONE}

(Possibly 200-300 $\mathrm{ft}$ exposed; at least $750 \mathrm{ft}$ thick in the Saddle Mountain quadrangle) Named by Ransome (1904). Occurs as lenses in hornblende diorite, much faulted, locally metamorphosed to skarn by the hornblende diorite. A slope-forming unit with characteristic outcrops resulting from evenly spaced resistant and less resistant beds. Most limestone is medium to thin bedded, fine grained, brownish to light gray, and weathers nearly white; local chert nodules and lenses. Contains fusilinids, brachiopods, corals, crinoids, bryozoans, and ostracods. Probably equivalent to the Horquilla Limestone, the lowest of six formations into which the Naco Group farther south has been divided (Gilluly and others, 1954, p. 6).

DIABASE

Dark-gray to dark-greenish or olive gray, fine to coarse-grained; diabasic to ophitic texture; composed of plagioclase, pyroxene, magnetite, ilmenite, olivine, and a little biotite and hornblende. Locally chlorite, epidote, sericite, quartz, and calcite alteration. The occurrence of diabase as sills in Precambrian sedimentary rocks and as sill-like masses in Precambrian granite and schist parallel to and not more than 500 feet below the base of the Apache Group is well illustrated on the geologic map. The narrow dikes(?) or sills(?) farther west and well below the base of the Apache are tentatively correlated with the Precambrian diabase. Many of them, notably the one mapped for nearly one mile and a half north of Romero Wash, are not more than $10 \mathrm{ft}$ wide. The diabâse is fine grained, dark gray, and fresh appearing in hand specimen, but too badly altered to obtain a meaningful isotopic age. Chemically, it is a little high in $\mathrm{SiO}_{2}$ and low in $\mathrm{TiO}_{2}$ for typical chilled Precambrian diabase in the Salt River Canyon area (A.F. Shride, written communication, 19.68), but similar in $\mathrm{SiO}_{2}$ and $\mathrm{TiO}_{2}$ content to diabase in Aravaipa Canyon. Chemical and normative compositions are given in table 3.

\section{TROY QUARTZITE (500-600 FT EXPOSED)}

Named by Ransome (1915) - Originally considered Cambrian in age, but now known to be Precambrian, as it is intruded by diabase; overlain paraconformably by Cambrian and (or) Devonian formations in adjacent areas (Krieger, 1961, 1968a-e, $1973 \mathrm{~b} ; \cdot$ and Shride, 1967). Crops out only north and south of Smith Wash, sec. 19, 29, 30, T. 5 S., R. 15 E., and south of Sample Wash, SE $1 / 4$ sec. '8, T. 6. S., R. 15 E. Consists of two units, not mapped separately in this area.

Upper unit: (eastern part of exposures north of Smith Wash and most or all of them south of the wash, where much of it is badly brecciated). White to very light gray, thin- to thick-bedded, feldspathic to non-feldspathic sandstone, quartzite, and granule to small-pebble conglomerate. Lower unit: Medium-gray to pale-red conglomerate and sandstone; mostly thin-bedded, lenticular, and channeled.

\section{APACHE GROUP}

Group, formations, and members named by Ransome (1903), except for Mescal Limestone (Ransome, 1915) 
and siltstone and arkose member of Dripping Spring Quartzite (Shride, 1967). TABLE 3.-Chemical and normative compositions of
diabase

[Analyses under direction of Leonard Shapiro, methods given in U.S. Geol. Survey Bull. 1144A; Y-19-64, analyzed by C.L. Parker, methods given in U.S. Geol. Survey Bull. 1170]

\begin{tabular}{|c|c|c|c|c|c|c|c|}
\hline $\begin{array}{l}\text { ield } \\
\text { No. }\end{array}$ & $\begin{array}{c}\text { W-55 } \\
\mathrm{A}\end{array}$ & & $\begin{array}{c}Y-19- \\
64\end{array}$ & & A & A-11 & 64 \\
\hline \multicolumn{4}{|c|}{$\begin{array}{l}\text { Chemical composition } \\
\text { (in percent) }\end{array}$} & \multicolumn{4}{|c|}{$\begin{array}{l}\text { CIPW Norms } \\
\text { (wt percent) }\end{array}$} \\
\hline$O_{2}$ & & 1.2 & 45 & Q & 6.8 & 2 & $\cdots$ \\
\hline & 13.0 & .5 & 16 & & 12.1 & 4. & 10.5 \\
\hline 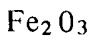 & 4.2 & 2.5 & 2. & & 25.2 & 21.6 & 26.4 \\
\hline 0 & 9. & 8.3 & 10. & & 17.0 & 26.5 & 27.8 \\
\hline g0 & 4 & 6.3 & 6 & & 5.9 & 10.7 & 2.7 \\
\hline 0 & 6 & 1.0 .5 & 7. & & 10.5 & 16.0 & 1.9 \\
\hline$d_{2}$ & & 2.5 & 3. & fs & 12.2 & 11.9 & 1.6 \\
\hline 20 & 2.0 & .7 & 1. & $\mathrm{f}$ & .... & $\ldots$ & 9.6 \\
\hline$I_{2} 0$ & & .1 & & $\mathrm{fa}$ & .... & .... & 9.1 \\
\hline${ }_{2} 0$ & 1.6 & 1.0 & 2. & & 6.2 & 3.7 & 3.7 \\
\hline $\mathrm{TiO}_{2}$ & 1.7 & 1.1 & 2. & il & 3.3 & 2.1 & 5.5 \\
\hline${ }_{2} 0_{3}$ & .2 & .1 & 4 & 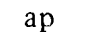 & .6 & .4 & 1.1 \\
\hline $\mathrm{MnO}$ & .2 & .18 & .19 & $\mathrm{cc}$ & .2 & .... & .0 \\
\hline $\mathrm{CO}_{2}$ & .11 & $<.05$ & .01 & \multicolumn{4}{|c|}{$\operatorname{Total}^{1 / 1} 100.09 \quad 100.0 \quad 100.03$} \\
\hline 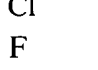 & & & .05 & \multicolumn{2}{|c|}{$\begin{array}{ll}\text { Salic } & 61.0 \\
\text { Femic } & 39.0\end{array}$} & \multirow{2}{*}{$\begin{array}{l}55.2 \\
44.9\end{array}$} & \multirow{2}{*}{$\begin{array}{l}64.8 \\
35.2\end{array}$} \\
\hline \multirow{2}{*}{\multicolumn{2}{|c|}{$\begin{array}{l}\text { Subtotal .... } \\
\text { Less 0-- }\end{array}$}} & \multirow{2}{*}{\multicolumn{2}{|c|}{$\begin{array}{rr}\ldots . & 100.03 \\
\ldots . . & .06 \\
\end{array}$}} & & & & \\
\hline & & & & \multirow{2}{*}{\multicolumn{4}{|c|}{$\begin{array}{l}{ }^{1 /} \text { In calculating norms, both } \\
\mathrm{H}_{2} \mathrm{O} \text {-and } \mathrm{H}_{2} \mathrm{O}+\text { were omit- } \\
\text { ted }\end{array}$}} \\
\hline Tot & 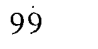 & ני & 7 & & & & \\
\hline
\end{tabular}

W-55 A - Winkelman quadrangle, north side of Romero Wash, center south edge $\mathrm{SW} 1 / 4 \mathrm{sec} .1, \mathrm{~T} .6 \mathrm{~S}$., R. 14 E.

A-11 - Upper chilled border, younger sill, Aravaipa Canyon, southeast of Brandenburg Mountain, Brandenburg Mountain quadrangle. Data from C.T. Wrucke (written commun.) 1970.

Y-19-64 Chilled border, lower contact of 780-foot sill, Gila County, Arizona. Data from A.F. Shride (written commun., 1968).

\section{MESCAL LIMESTONE (0-250 FT)}

Exposed only on east side of ridge of Apache Group rocks, north and south of Smith Wash and north and south of Sample Wash. Thin- to thick-bedded, paleto dark-brown and light-olive-gray dolomite and silty to cherty dolomite, some red to pink, thinly laminated dolomite; brown dolomitic sandstone locally at base. Metamorphosed near diabase to white crystalline limestone and yellowish-gray silicated limestone.

\section{DRIPPING SPRING QUARTZITE (350;500 FT)}

Siltstone member (at least $250 \mathrm{ft}$ )-Thin-bedded (1/412 in.), very fine grained, feldspathic to arkosic quartzite and siltstone that is shades of gray, brown, red, and yellow. Mostly poorly exposed and talus covered.

Arkose member (150-200 ft)-Medium-grained, locally fine- to coarse-grained, thin- to thick-bedded, crossbedded, red to pink feldspathic to arkosic quartzite. The lower $50 \mathrm{ft}$ or so is pale-yellowish-brown to light-brownish-gray, fine-grained quartzite and sandstone, and grayish-red-purple siltstone and fine-grained sandstone that resembles many beds in the Pioneer Formation.

Barnes Conglomerate Member (0 to more than $50 \mathrm{ft}$, absent only in southwestern outcrops, where resistant jasper-magnetite lenses protrude above the general level of the Pinal Schist) - Ellipsoidal, extremely well rounded pebbles ( $1 / 4$ to 6 in.) of quartzite, quartz, and red jasper, mostly closely packed, locally sparsely scattered in a matrix of red to gray arkosic sandstone or quartzite; locally, large cobbles and boulders of jasper-magnetite near highs in the Pinal Schist. Pitted surfaces on pebbles are found in several places and are especially common north of Romero Wash. They formed during deformation where pebbles were so closely packed that they were crushed at points of contact. Continuing deformation has fractured some pitted pebbles, and the fractures have later been healed. Pitted pebbles do not appear to weather out of the matrix faster than unpitted ones.

PIONEER FORMATION (0-ABOUT 300 FT)

Upper member (0 - over $250 \mathrm{ft}$ ).-Dark-red to purple mudstone, siltstone, and very fine grained sandstone with numerous pale-red to yellowish-gray elliptical leached spots; interbedded with light-colored and reddish-orange, fine- to medium-grained, crossbedded arkosic sandstone and some dark-red to purple, coarsegrained sandstone. Many beds are tuffaceous. Mostly poorly exposed and talus covered.

Scanlan Conglomerate Member (0 - about $30 \mathrm{ft})$.Subangular to ellipsoidal pebbles and cobbles of quartz, quartzite, and locally of Pinal Schist or jasper-magnetite from the Pinal in an arkosic matrix. In some places the member is composed almost entirely of fragments derived from the Ruin Granite; where small angular to rounded pebbles of quartz are absent, the exact contact with the underlying granite may be difficult to recognize.

APLITE

Narrow dikes of pinkish- to yellowish-gray aplite in Ruin Granite and a few larger masses in Pinal Schist; includes some aplitic alaskite and pegmatite: May include some dikes of Laramide age, as aplite locally intrudes Late Cretaceous granodiorite and diorite.

RUIN GRANITE AND RELATED ROCKS

Named by Ransome (1963); same as Oracle Granite of N.P. Peterson (1938). Coarse-grained, porphyritic, pinkish- to yellowish-gray quartz monzonite speckled with dark biotite books (as large as $5 \mathrm{~mm}$ ) and containing euhedral, somewhat poikilitic and perthitic phenocrysts of microcline and microperthite (as large as $4 \times 2 \mathrm{~cm}$ ); somewhat zoned and sericitized plagioclase (mostly less than $1 \mathrm{~cm}$ ); quartz as rounded crystals (about $6 \mathrm{~mm}$ ) and as finer intergrow ths with microcline; accessory magnetite and apatite; biotite locally altered to a mixture of magnetite and chlorite.

Associated with the Ruin Granite are dikes, lenses and irregular masses of light-colored aplitic alaskite, alaskite porphyry, and aplite. These finer grained rocks riddle the Ruin in many areas and form many of the ridge tops, owing to greater resistance to erosion. Red and pink alaskite or aplite is abundant immediately west of the ridge of Apache Group rocks. According to Silver (1968) the age of granite (quartz monzonite) in Arizona is $1,430-1,460$ m.y. based on U-Pb isotope system in zircon; biotite from the Ruin (Oracle) Granite 
near Oracle gave an age of 1,420 m.y. by the K-Ar method according to Damon and others (1962).

\section{PINAL SCHIST}

Named by Ransome (1903). Dark- to medium-lightgray, dense, very fine grained, massive, to flowbanded(?) and schistose rocks of rhyolitic to andesitic composition; some volcanic(?) conglomerate. Lithologic units trend northeast but have not been separated in mapping. North of Smith Wash, much of the formation consists of spotted schist. South of Smith Wash, much of it probably was flow-banded rhyolite or dacite. Southwestern outcrops are of quartz-sericite spotted schist, andesitic flows(?), volcanic conglomerate and (or) flow breccia, feldspar-quartz porphyries, and lenses of jasper-magnetite or quartz-hematite that may represent beds or replacement veins. Some of the porphyries may have been flows; others probably were ash-flow tuffs.

\section{REFERENCES}

Banks, N.G., Cornwall, H.R., Silberman, M.L., Creasey, S.C., and Marvin, R.F., 1972. Chronology of intrusion and ore deposition at Ray, Arizona: Econ. Geology, v. 67, no. 7, p. 864-878.

Blake, W.P., 1903, Arizona diatomite: Wisconsin Acad. Sci. Trans., v. 14, p. 107-111.

Cornwall, H.R., Banks, N.G., and Phillips, C.H., 1971, Geologic map of the Sonora quadrangle; Pinal and Gila Counties, Arizona: U.S. Geol. Survey Geol. Quad. Map GQ-1021, scale 1:24,000.

Cornwall, H.R., and Krieger, M.H., in preparation, Geologic map of the Kearny quadrangle Pinal County, Arizona: U.S. Geol. Survey Geol. Quad Map GQ1188, scale $1: 24,000$.

Creasey, S.C., 1965, Geology of the San Manuel area, Pinal County, Arizona, with a section on Ore deposits by J. D. Peletier and S.C. Creasey: U.S. Geol. Survey Prof. Paper 471, 64 p.

1967, General geology of the Mammoth quadrangle, Pinal County, Arizona: U.S. Geol. Survey Bull. 1218, 94 p.

Damon, P.E., Livingston, D.E., and Erickson, R.G., 1962, New K-Ar dates for the Precambrian of Pinal, Gila, Yavapai, and Coconino Counties, Arizona in New Mexico Geol. Soc. Guidebook, 13 Field Conf. Mogollon Rim Region, east-central Arizona, p. 5657.

Damon, P.E., Mauger, R.L., and Bikerman, Michael, 1964, K-Ar dating of Laramide plutonic and volcanic rocks within the Basin and Range Province of Arizona and Sonora: Internat. Geol. Cong. 22d, New Delhi, India, pt. 3, Sec. 3, Proc. p. 45-55.

Evensen, J.M., 1961, Geology of the Copper Hill area, Winkelman, Arizona: Arizona Univ., Tucson, M.S. thesis; abstract published 1961 in Arizona Geol. Soc. Digest, v. 4, p. 178-179.

Gilluly, James, Cooper, J.R., and Williams, J.S., 1954, Late Paleozoic stratigraphy of central Cochise County, Arizona: U.S. Geol. Survey Prof. Paper 266, 49 p.

Heindl, L.A., 1963, Cenozoic geology in the Mammoth area, Pinal County, Arizona: U.S. Geol. Survey Bull. $1141-\mathrm{E}, 41 \mathrm{p}$.

Krieger, M.H., 1961, Troy quartzite (younger Precambrian) and Bolsa and Abrigo Formations (Cambrian), northern Galiuro Mountains, southeastern Arizona, in Geological Survey research 1961 ; U.S. Geol. Survey Prof. Paper 424-C, p. C160-C164.

1968a, Geologic map of the Brandenburg Mountain quadrangle, Pinal County, Arizona: U.S. Geol. Survey Geol. Quad. Map GQ-668, scale 1:24,000.

1968 b, Geologic map of the Holy Joe Peak quadrangle, Pinal County, Arizona: U.S. Geol. Survey Geol. Quad. Map GQ-669, scale 1:24,000.

$1968 c$, Geologic map of the Lookout Mountain, Pinal County, Arizona: U.S. Geol. Survey, Geol. Quad. Map GQ-670, scale 1:24,000.

Krieger, M.H., 1968d, Geologic map of the Saddle Mountain quadrangle, Pinal County, Arizona: U.S. Geol. Survey Geol. Quad. Map GQ-671, scale $1: 24,000$

1968e, Stratigraphic relations of the Troy Quartzite. (Younger Precambrian) and the Cambrian formations in southeastern Arizona, in Southern Arizona Guidebook III (Geol. Soc. America, Cordilleran Sec., 64th Ann. Mtg., Tucson, 1968): Tucscon, Ariz., Arizona Geol. Soc., p. 22-32.

1974b, Geologic map of the Crozier Peak quadrangle, Pinal County, Arizona: U.S. Geol. Survey Geol. Quad. Map GQ-1107, scale 1:24,000.

1974 c, Geologic map of the Black Mountain quadrangle, Pinal County, Arizona: U.S. Geol. Survey Geol. Quad. Map GQ-1 108, scale 1:24,000.

1974d, Geologic map of the Putnam Wash quadrangle, Pinal County, Arizona: U.S. Geol. Survey Quad. Map GQ-1 109, scale 1:24,000.

$1974 \mathrm{e}$, Generalized geology and structure of the Winkelman 15-minute quadrangle and vicinity, Arizona: U.S. Geol. Survey Journal of Research, v. 2, no. 3 [in press].

Krieger, M.H., Cornwall, H.R., and Banks, N.G., 1973, The Big Dome Formation and revised Tertiary stratigraphy in the Ray-San Manuel area, Arizona in Changes in stratigraphic nomenclature: U.S. Geol. Survey Bull. 1394-A [in press].

McAllister, J.F., 1970, Geology of the Furnace Creek borate area, Death Valley, Inyo County, California: Div. Mines and Geology Map Sheet 14, text 9 p.

Peterson, N.P., 1938, Geology and ore deposits of the Mammoth mining camp area, Pinal County, Arizona: Arizona Bur. Mines Bull. 14A, Geol. Ser. 11 (Arizona Univ. Bull.,v. 9, no. 2), 63 p.

Ransome, F.L., 1903, Geology of the Globe copper district, Arizona: U.S. Geol. Survey Prof. Paper 12, $168 \mathrm{p}$.

1904, Geology and ore deposits of the Bisbee Quadrangle, Arizona: U.S. Geol. Survey Prof. Paper $21,168 \mathrm{p}$.

1915, The Paleozoic section of the Ray quadrangle, Arizona: Washington Acad. Sci. Jour. 5, no. 11 , p. $380-388$.

1919, The copper deposits of Ray and Miami, Arizona: U.S. Geol. Survey Prof. Paper 115, 192 p.

Shride, A.F., 1967, Younger Precambrian geology in southern Arizona: U.S. Geol. Survey Prof. Paper 556, 89 p.

Silver, L.T., 1960, Age determinations on Precambrian diabase differentiates in the Sierra Ancha, Gila Counties, Arizona [abs.] : Geol. Soc. America Bull., v. 17, no. 12 , p. 2 , p. $1973-1974$.

1968, Precambrian batholiths of Arizona [abs.] : 
Geol. Soc. America, Cordilleran Sec., 64th Ann. Mtg., Tucson, Ariz. Program, p. 109-110.

Simons, F.S., 1964, Geology of the Klondyke quadrangle, Graham and Pinal Counties, Arizona: U.S.
Geol. Survey Prof. Paper 461, 173 p. Willden, Ronald, 1964, Geology of the Christmas quadrangle, Gila and Pinal Counties, Arizona: U.S. Survey Bull. 1161-E, p. E1-E64. 